

\section{What's in it for me?}

\section{MANCHESTER 1824}

Manchester University Press 
Thomas Prosser - 9781526152343

Downloaded from manchesterhive.com at $04 / 26 / 2023$ 02:35:25PM via free access 


\section{What's in it \\ for me?}

\section{Self-interest and political difference}

\section{Thomas Prosser}

Manchester University Press 
Copyright (C) Thomas Prosser 202 I

The right of Thomas Prosser to be identified as the author of this work has been asserted by them in accordance with the Copyright, Designs and Patents Act I988.

Published by Manchester University Press

Altrincham Street, Manchester MI 7JA

www.manchesteruniversitypress.co.uk

British Library Cataloguing-in-Publication Data

A catalogue record for this book is available from the British Library

ISBN 978 I 526I 52329 hardback

ISBN 978 I 526I 523 I 2 paperback

First published $202 \mathrm{I}$

The publisher has no responsibility for the persistence or accuracy of URLs for any external or third-party internet websites referred to in this book, and does not guarantee that any content on such websites is, or will remain, accurate or appropriate.

Typeset by Newgen Publishing UK 